\title{
INDUSTRIAL DEMOCRACY IN HUNGARY
}

\author{
Alexander Szakats*
}

This article describes the nature of industrial democracy in Hungary under the Labour Code 1992, and compares the role of Work Councils with that of trade unions.

\section{INTRODUCTION}

With the breaking up of the Soviet Union, the Communist regime in Hungary also expired. It never was popular, the occupying power kept it alive. No revolution brought about the end of the rule, it simply lost its force. When home-grown party functionaries took over from the Moscow hirelings, they had to relax the former rigidity, first very carefully not to invoke another harsh reversal by the Kremlin, but after the demise of Breznev, more openly. Private enterprise increased, many individual shops, restaurants and tradesmen opened business and gave much better service than the badly run state industry. With free speech, criticism of the regime grew louder and broadsheets, previously circulated underground, appeared as newspapers openly sold.

Following the events in 1989, the new democratic constitution and other laws replaced the Soviet style labour system with a Labour Code ${ }^{1}$ appropriate to the employment relationship between privately owned business and individual workers. The freely elected Parliament passed it in 1992. In order to prevent the possibility of capitalist exploitation great emphasis was placed on the safety and human rights of employees.

A previous article ${ }^{2}$ highlighted some provisions of the Code which protect employees, ${ }^{3}$ especially female workers, youth and disabled persons. The human rights of

* Dr Iur, DrPol(Budapest), LLB(NZ), Emeritus Professor of Law (Otago), Employment Law Consultant.

1 Munka Törvénykönyv, 1992 XXII statute, Labour Code (the Code).

2 A Szakats "Human Rights in the Hungarian Labour Code" (1997) 3 Yearbook NZ Association for Comparative Law, 573; (1998) 28 VUWLR 573.

3 The words "worker" and "employee" are used interchangeably. 
workers as an entity within an enterprise have been recognised not only allowing freedom of organisation in trade unions, but establishing a general industrial democracy through Work Councils. ${ }^{4}$

Chapter IV of the Code prescribes detailed rules on the election, constitution and powers of the Council but some other provisions are also relevant to its functions, and reveal interdependence between the Council and trade unions in respect of some rights and powers.

Before examining Work Councils in Hungary, it is necessary to look into the origin and development of industrial democracy as a concept and practice elsewhere.

\section{WHAT IS INDUSTRIAL DEMOCRACY?}

The economic view that workers are mere tools in the production process of goods, the other side of the capital versus labour equation, receiving wages as their full reward, has been attacked for a long time arguing that the meagre wages do not recognise workers' contribution to the increase of assets. In simple words: the profit earned benefits capitalists only, the workers' share due to their sweat, toil and exertion is denied to them; exploiting capitalists "stole" it.

This age old contention has remained current even today, despite - or perhaps because of - strong trade unions. Should capital and labour fight forever as enemies? Must they always be adversaries in conflict? More and more politicians, academics, employers and trade union leaders posed this question. Enlightened employers as well as pragmatic trade unions realised that an inflexible hostile attitude causes damage to both. They looked for a solution whereby employees would have at least some interest in the business of their employer, mostly a big impersonal corporation. Shareholders of companies, as contributors of capital have an interest and some control in the management (little or substantial depending on the number of shares held), but contributors of labour, although without them no enterprise would function, are denied any direct involvement.

Industrial democracy originated in the German Reich at the beginning of the 20th century. The first Work Councils were formed in the Prussian mines in 1905. During the First World War, to prevent any disruption in armament production, Work Councils were made compulsory not only in heavy industry but in every enterprise. During the Weimar Republic this arrangement remained in force. The Nazi regime drove all democratic workers' organisations underground, but in 1945 the unions reappeared as a strong democratic force and decisively influenced the rebuilding of the German state and

4 Hereinafter referred to as "the Council". 
economy. The Allied Military Government agreed to re-establish the heavy industry in a democratic environment, and favoured revival of Work Councils. ${ }^{5}$

After the British, American and French occupancy zones united in 1949 as the sovereign German Federal Republic, the German Trade Union Federation at its inaugural congress formulated a policy statement which, among other things, demanded legislative recognition of industrial democracy and codetermination of organised labour. ${ }^{6}$

The freely elected Parliament accepted the principle of codetermination and passed two statutes: The Codetermination Act 1951 and the Works Constitution Act $1952 .{ }^{7}$ These statutes were amended or replaced by later enactments. Despite subsequent revision, the Acts may be regarded as the foundation stones of all presently extant industrial democracy laws.

These statutes created two different forms of industrial democracy: partial codetermination and full codetermination. The first provides for a Works Council with limited powers, while the full one entitles the employees to more direct involvement in the managing body of a corporate enterprise.

A Works Council has jurisdiction only in matters directly affecting employees. In the case of full codetermination at least one worker will be a director, and as such has the same right to express a view - the workers' view - and vote on issues of commercial policy, capital investment, finance, export initiatives, retail price of products and in general every matter important to successful and profitable business. Full codetermination operates only in a few industries, mainly in the coalmines and the associated German steel factories. ${ }^{8}$

The German model was followed in Austria, Belgium, Luxembourg and the Netherlands where legislation introduced similar partial codetermination systems. ${ }^{9}$

In other countries the German system did not find favour. Not only employers opposed it, but also workers organisations. Strong trade unions do not wish to participate in management, they prefer the adversary situation. "We don't want to sit on the same side

5 Helga Grebing The History of German Labour Movement (D Wolff, London, 1969) Ch VIII.

6 Grebing, above n 5, 175.

7 Mitbestimmungsgezetz, 21 May 1951; Betriebsverfassungsgezets, 11 October 1952.

8 Grebing, above n 5; see also Hans Schactschabel, "Die Mitbestimmung der Arbeitsnehmer in der Wirtschaftsfuhrung der Unternehmung auf betrieblicher Ebene in der 44 Auffassung der Gewerkschaften und der Arbeitsgeberverbande" in Zur Theorie und Praxis; der Mitbestimmung, ed W Weddingen.

9 Judy Brown "Implications for the Disclosure of Financial Information" (1999) 2 Employment Law Bulletin 25, 27. 
of the table"; this would weaken the bargaining process with the employer as the opposite party. Disclosure of financial information, nevertheless, is demanded as a prerequisite to fair bargaining.

The National Labour Relations $\mathrm{Act}^{10}$ in the United States imposing the duty "to bargain in good faith" includes the obligation that the employer must provide to the union "all information relevant and necessary" to such bargaining; this concerns the financial situation of the employer. In England the Trade Unions and Labour Relations (Consolidation) Act 1992 orders disclosure of financial information necessary for collective bargaining. ${ }^{11}$

The United States and English Acts illustrate a different approach for the same purpose: enabling workers to secure better conditions.

\section{WORK COUNCILS IN HUNGARY: CONSTITUTION}

Chapter IV of the Code bears the title: "The Participation Rights of Employees". Sections 42-70 provide for the establishment of Work Councils in any enterprise employing workers. Distinct from the method of legislation which sets out general principles leaving detail for regulations, these sections prescribe all procedural steps. Substantive powers are provided in relatively few sections. It should be remembered, however, that in certain branches of the law procedure equals substance. ${ }^{12}$

Some of the procedural steps must be closely examined for this very reason.

Every workplace employing more than 50 workers should elect a Works Council. ${ }^{13}$ The number of Council members depends on the size of the enterprise: three in cases of up to 100, gradually increasing to 13 for over 2000 employees. In businesses employing less than 50 but at least 15 persons, a single workers' representative will suffice. Where the number is less, as in a small grocer shop or a tradesman with a few assistants, mostly a family business, formal employee representation has not been considered a requirement. ${ }^{14}$ Where a corporate employer carries on its trade in several localities, every separate plant should elect a Council, but at the same time a Central Council must also be formed, to

10 Frequently quoted as the Wagner Act of 1935.

11 Brown, above n 9, 25.

12 For example in bankruptcy proceedings a person may in fact be insolvent but only adjudication by court will make him or her bankrupt. See Insolvency Act 1967 (NZ).

13 Section 43 of the Code.

14 Section 45 of the Code. 
which the Central Council should delegate members in proportion to the number of workers employed there. ${ }^{15}$

An election committee must be formed from the workers at least eight weeks before the date of election. All employees are entitled to vote for its members. The committee has to compile a list of voters on the basis of information provided by the employer within five days of the request for it; this list must be published not later than three weeks before the election. Trade unions, through one of their officials, may be included in the committee but the chairman of the outgoing Council is debarred.

The committee:

(1) determines the last day for nominating candidates and the time of the election,

(2) ensures the legality of nominations and order of the voting, and

(3) determines the detailed rules of vote counting.

Ten percent of the employees, or at least 50, may nominate a candidate in writing for the Council. Every trade union functioning at the workplace has a right to independent nomination, and every nominated person must give a written acceptance of candidacy.

Only workers employed for at least six months may stand for election. ${ }^{16}$

The election committee prepares the voting papers listing the candidates in alphabetical order with trade union affiliation where applicable. Voting is secret and immediate. When the election is declared valid, the candidates who received the majority of valid votes, and gained at least 30 percent, will be Council members. In cases of an equal vote the length of previous employment will be the decisive factor. ${ }^{17}$

The election is invalid when less than half of the employees voted. In such an event new elections must be held after 30, but within 90 days. The second election will be valid if at least one third of the voters participate.

The election will also be unsuccessful when the candidates, or any of them, fail to receive the required 30 percent of votes. Those who did must be regarded as elected members, and for the missing places a new election should be held within 30 days. New

\footnotetext{
15 Section 44 of the Code.

16 Sections 46, 47, 48, 48A, and 49 of the Code.

17 Sections 50, 51 of the Code.
} 
candidates may be nominated until the 15th day before the new election. Those who received 20 percent of the votes will be regarded as alternate reserve members. ${ }^{18}$

After the voting has finished the ballot boxes must be opened at the same time recording:

(1) the circumstances of the opening;

(2) the place and time of the election;

(3) the number of workers entitled to vote;

(4) the number of employees who voted;

(5) the number of votes received;

(6) the number of valid and invalid votes;

(7) the number of votes for each candidate;

(8) the name of the elected members and alternate members; and

(9) any argument regarding the election and its solution.

Every committee member should sign this record which is to be published in the usual manner and held by the Council. In cases of an invalid election, this duty is on the employer. 19

If any dispute arises from the election, either party may initiate conciliation within five days, during which the committee and representatives of the trade unions should reach an agreed decision. Against this, either party may appeal to the Labour Court. ${ }^{20}$

The Council is elected for three years ${ }^{21}$ but it may be dissolved at any time when:

(1) the employer ceases trading;

(2) it is recalled;

(3) the number of members is reduced more than by one third;

(4) the number of employees sinks under 50 or by two thirds;

(5) several workplaces are merged; and

18 Sections 51(3)-(7), and 52 of the Code.

19 Section 53 of the Code.

20 Section 54 of the Code; Labour Court decision BH1993 583.

21 Section 43(4) of the Code. 
(6) a workplace is divided.

Recalling of the Council may be initiated by at least 30 percent of the voters in writing. Two thirds approval is then required at a subsequent vote of not less than half of the employees to make it effective.

The mandate of a Council member will terminate by:

(1) abdication;

(2) recall;

(3) loss of legal capacity;

(4) becoming entitled to exercise employer's rights for more than 6 months;

(5) becoming a close relation of the employer;

(6) the dissolution of the Council; and

(7) leaving the employment. ${ }^{22}$

The first meeting of the Council should be held 15 days after its valid formation; one member is to be elected chairperson. For a quorum, attendance of at least half of the members is necessary. The decisions are reached by majority vote. ${ }^{23}$

\section{THE POWERS OF THE COUNCIL}

A validly elected Works Council has significant powers in protecting all employees, union members and non-members alike, working at the same enterprise. It must not be hindered in publishing notices, requests and information at the workplace in the usual manner. ${ }^{24}$ This publishing of information to the employees is not to be confused with publishing facts and data to the general public concerning the employer's business learned by the Council in the course of its legitimate functions. Such publication is prohibited if it would jeopardise the employer's lawful economic interests or hurt the personal rights of individual workers. ${ }^{25}$

One of the important rights provides for co-decision with the employer: it concerns using funds for welfare purposes as defined in the applicable Collective Agreement, and for the best administration of institutions and real property for the same objective.

22 Section 55 of the Code.

23 Sections 59 and 60 of the Code.

24 Section 62(1) of the Code.

25 Section 69 of the Code. 
The employer is obliged to seek the Council's opinion before deciding on:

(1) any plan affecting a sizeable group of employees regarding restructuring, privatisation and modernisation of the enterprise;

(2) personnel record systems;

(3) any plans for trade training, promoting employment and pensions for concession workers;

(4) rehabilitation of employees with reduced working capacity;

(5) annual holiday plans;

(6) introduction of new working methods and output requirements;

(7) plans of work rules affecting employees' essential interests; and

(8) competitions promising material or moral reward. ${ }^{26}$

The employer is bound when the Council demands it to supply information on:

(1) all fundamental issues affecting the employer's economic situation a minimum of six monthly intervals;

(2) plans of essential modification of business activities and investments; and

(3) wage trends, liquidity for wage payment, characteristics of tasks performed, and conditions and use of working time, in every half year. ${ }^{27}$

The Council must advise the employer on questions to be jointly decided within 15 days, otherwise concurrence is presumed. Apart from this, the employer's decision without the Council's agreement will be invalid. In connection with such matters the Council has the right to peruse the employer's records. ${ }^{28}$

As members of the Council cannot perform their usual work when engaged in Council activities the Code entitles them to reduction of worktime: 15 per cent for the chairperson and 10 per cent for members; but if agreed, it can be more, with a maximum of 50 per cent. For that period they are entitled to an absence fee. ${ }^{29}$ The employer is also obliged to bear all justified expense in respect of the election and functioning of the Council. The amount

26 Section 65(1)(3) of the Code.

27 Section 65(4) of the Code.

28 Sections 66, 67, and 68 of the Code.

29 Section 62(2) of the Code. 
will be as agreed by the employer and the Council; in the case of an argument, by arbitration. ${ }^{30}$

Where more than 1000 workers are employed, the chairperson of the Council receives a fee from the employer, as agreed with the Council. ${ }^{31}$

\section{THE INTERRELATION BETWEEN THE COUNCIL AND TRADE UNIONS}

The necessity for a Work Council has been questioned on the ground that it merely duplicates the protection of workers, a task which trade unions have always performed, and perform, satisfactorily. In support of this view the argument points out that workers' organisations in general are granted the same or similar rights. Thus, the provision in section 24(1) of the Code directing the employer to ensure that every piece of information, summons or notice relating to the union's activities be published to its members in the usual, or a proper, manner practically repeats the wording of section 62 which gives the same right to the Council. ${ }^{32}$ This is true, but no organisation could properly function in isolation from its members.

Unions are also entitled to receive information from the employer on any matter affecting workers' economic and social interests, to a right of consultation, ${ }^{33}$ to inspect observation of workrules, and to point out any errors and omissions. If such complaints are rectified, they have the right of objection against any order and arrangement. Such rights, in any case, are accessory to a union's position. ${ }^{34}$

One of the essential aspects of any union's activity is collective bargaining. Making a collective agreement is outside the purview of the Works Council, a trade union independent body has the qualification. ${ }^{35}$ As, however, several trade unions exist at the same workplace, the Council, or rather its composition, will be the decisive fact selecting the union, or unions, which can negotiate and make a collective agreement. ${ }^{36}$

30 Section 63 of the Code.

31 Section 64 of the Code.

32 See above part IV.

33 Section 22(1) of the Code.

34 Section 22(2) and (3) of the Code.

35 Section 32 of the Code.

36 Sections 31-33 of the Code; see Szakats, above $\mathrm{n} 2$ where trade unions and collective bargaining are dealt with in detail. 
Other provisions in the Code also create interdependence between the two different bodies. Representatives of trade unions may participate in the work of the election committee, ${ }^{37}$ a union is entitled to nominate its own candidate for the Council. ${ }^{38}$ When the mandate of a unionist Council member expires, the place vacated must be taken by the person from the same union who gained most votes after the departing member. ${ }^{39}$

It may be firmly stated that the rights and powers of the Works Council does not abrogate, nor even reduce, the importance of the unions. They are of a different character, operate on a different level and occupy contrasting positions.

A trade union is present at the workplace through its members, not as part of the enterprise but as an outside organisation independent from the employer. It aims at protecting the workers, promoting their interests as an adversary, though not invariably hostile to the management of the enterprise. The protection, however, strictly speaking, extends to its members only, shared with rival unions and leaving non-unionist employees out. When a union, or its members, considers that the employer acts unfairly it can take a militant stance and commence direct action. Interruption of normal production causes financial loss to the employers which purports to force the employer into accepting, at least partly, the claim.

A Works Council functions not as an adversary, but as an essential component of the enterprise with a voice in the managerial decision-making process. Although the Council's power is limited to matters affecting workers, and lacks the full rights of directors, its opinions representing all employees certainly influence the governing body of a corporation and any employer.

While it may be asserted that the Code through Work Councils provides only for limited workers' participation in management, its undoubted purpose remains - beside representing and protecting all workers - that of harmonising employees' well-being with the employer's prosperity.

DE L'INFLUENCE DES RÈGLES DÉMOCRATIQUES DANS LE DROIT DU TRAVAIL HONGROIS

La disparition du régime communiste en Hongrie a été l'une des nombreuses conséquences du démantèlement de l'Union soviétique.

37 Section $49(1)$ of the Code.

38 Section 49(3) of the Code.

39 Section 55A(2) of the Code. 
A la suite des événements de 1989, la nouvelle constitution hongroise et le nouveau cadre législatif ont abandonné l'ancien modèle soviétique notamment en matière de droit du travail.

Le nouveau code du travail hongrois de 1992 reflète ce nouvel état d'esprit. Dans cet article, l'auteur décrit quelles sont les lignes directrices du nouvel arsenal juridique mis en place et s'attache plus particulièrement à considérer quelle sont les rôles et les pouvoirs encore accordés aux syndicats ouvriers dans ce nouveau contexte. 
